\title{
Retraction Note: Coastal meteorological characteristics based on big data and financial tax optimization of urban enterprises
}

\author{
Zhou $\mathrm{Li}^{1} \cdot$ Che Ping ${ }^{2}$
}

Published online: 17 November 2021

(c) Saudi Society for Geosciences 2021

Retraction Note: Arabian Journal of Geosciences (2021) 14: 1499

https://doi.org/10.1007/s12517-021-07892-9

The Editor-in-Chief and the Publisher have retracted this article because the content of this article is nonsensical. The peer review process was not carried out in accordance with the Publisher's peer review policy. Author Che Ping has not responded to correspondence regarding this retraction. The Publisher has not been able to obtain a current email address for author Zhou Li.

The original article can be found online at https://doi.org/10.1007/ s12517-021-07892-9.

Che Ping

zhouli_2020841@126.com

1 College of Finance and Taxation, Jiangxi Vocational College of Finance and Economics, Jiujiang 332000, China

2 Normal College, JiuJiang Vocational University, Jiujiang 332000, China 